\title{
Investigation of Prospective Preschool Teachers' Beliefs about Mathematics Teaching and Learning
}

\author{
Zeynep Bahar Erşen ${ }^{凶 1}$, Nimet Akin² \& Fatih Karakuş ${ }^{3}$ \\ 1 Department of Mathematics and Science Education, Selcuk University, Konya, Turkey \\ 2 Department of Mathematics and Science Education, Afyon Kocatepe University, Afyonkarahisar, \\ Turkey \\ ${ }^{3}$ Department of Mathematics and Science Education, Sivas Cumhuriyet University, Sivas, Turkey \\ $\bowtie$ zbahar.ersen@selcuk.edu.tr
}

\begin{abstract}
Preschool teachers' beliefs about mathematics are crucial for qualified mathematical learning environments because children need to develop mathematical concepts based on their level of mathematical knowledge. Therefore, the purpose of this research is to determine prospective preschool teachers' beliefs about mathematics teaching and learning and to examine the effect of different variables on these beliefs. This research involved 884 prospective preschool teachers as the research sample at three state universities in Turkey. A belief Scale on mathematics teaching and learning was used as a data collection tool. The results showed that prospective teachers had positive beliefs about mathematics teaching. Moreover, there was a significant difference on prospective teachers' beliefs in accordance with grade levels. On the other hand, according to the type of prospective teachers' high school graduation, there was a significant difference in favor of prospective teachers who graduated from vocational high schools in the "mathematical learning" and "nature of mathematics" sub-scales of the scale.
\end{abstract}

Keywords: Preschool, mathematics teaching, mathematics learning, belief in mathematics, prospective preschool teacher

\footnotetext{
How to Cite: Erşen, Z., Akin, N., \& Karakuş, F. (2021). Investigation of Prospective Preschool Teachers' Beliefs about Mathematics Teaching and Learning. Mimbar Sekolah Dasar, 8(2), 149-178. doi:https://doi.org/10.53400/mimbar-sd.v8i2.33486.
}

INTRODUCTION Preschool education covers the childhood years from birth to primary school, provides a rich variety of stimulating environmental opportunities suitable for the individual characteristics and development levels of children in these ages and guides children through each developmental step in line with the cultural values and characteristics of the society (Oğuzkan and Oral, 1997). Besides being the fastest period of development, the preschool period is indicated by the acquisition of the foundations of the concept and knowledge of mathematics for children. The National Council for Teachers of Mathematics (2000) stated that the concepts of mathematics is initially acquired in the first years of life and continue to be gained during preschool, primary education, secondary education, and higher education periods. Therefore, the build-up of love, enthusiasm, and positive attitudes towards mathematics in formal education years starting with primary school years is directly related to preschool mathematics experiences. Preschool years are definitely critical as the period of establishing the foundations of many mathematical concepts (Oktay, 2000). 
Zeynep Bahar Erşen, Nimet Akin \& Fatih Karakuş, Investigation of Prospective Preschool Teachers'...

Since children have different levels of mathematical knowledge, preschool teachers assume important responsibility while providing pupils with qualified informal mathematics education (Güven et al., 2012; Todd-Brown, 2003). Preschool teachers assume more important and different missions than teachers practicing at other educational levels due to their role as representatives of their children's parents (Gürkan, 1981). Preschool teachers should prepare qualified teaching programs considering different mathematical knowledge levels in order to develop the necessary mathematical concepts for children. Furthermore, they should offer such programs to children at different times through a variety of activities (Wortham, 2006).

Helping children develop mathematical concepts constituting a spiral pattern of knowledge extending to every stage of life may seem quite complicated. Preschool teachers should realize that children's mathematical beliefs develop as a process (Baki and HacısalihoğluKaradeniz, 2013; Tarım and Bulut, 2006). During such processes, the beliefs of teachers and the learning environments built by teachers based on such beliefs develop students' beliefs about mathematics (Carter and Norwood, 1997; Ernest, 1989; Pajares, 1992; Thompson, 1992).

Mathematical beliefs constitute the person's approach to mathematics and mathematical tasks (Schoenfeld, 1989). Raymond (1997) defined mathematical beliefs as personal judgments about mathematics and argued that such beliefs, including the beliefs about learning, teaching, and the nature of mathematics are shaped by mathematical experiences. According to McLeod (1992), mathematical beliefs can be examined in four dimensions: beliefs about the nature of mathematics, beliefs about learning mathematics, beliefs about teachers' roles in learning mathematics, and beliefs in the social context. Ernest (1989) developed a model about mathematical beliefs and described mathematical beliefs as the individual's insights, values, ideology, and tendencies toward mathematics. The Ernest model consists of three following conceptions, including instrumentalist, Platonist, and problem-solving views. Teachers having instrumental beliefs see mathematics as a compilation of unrelated rules and facts. Teachers with a Platonist belief consider mathematics as an unchanging set of information based on related structures and facts. The Platonist view considers that mathematical information is not created but rather the existing information is discovered. According to the teacher with the problem-solving view, mathematics is a constantly expanding, dynamic, and problem-based knowledge generation process (Kul, 2017). Ernest (1982) argues that such beliefs are systematic with a mechanism of operation starting from the instrumental belief to the problem-solving view. In this context, the instrumental belief lies at the lowest hierarchical level, whereas the problem-solving belief stands at the highest level (Dede and Karakuş, 2014).

Many studies focused on the mathematical beliefs of either teachers (Barkatsas-Tasos and Malone, 2005; Karakuş, 2015; Yu, 2008) or prospective teachers (Ambrose et al., 2004; Cady and Rearden, 2007; Dede and Karakuş, 2014; Duru and Göl, 2016; Kayan et al., 2013; Swars et 
al., 2007). In addition, a few studies address the mathematical beliefs of preschool teachers or prospective preschool teachers who do or will assume one of the most critical roles in developing students' beliefs about mathematics (Ginsburg et al., 2008; Güven et al., 2012; Kilpatrick et al., 2001; Lee and Gingsburg, 2007). The review of the studies in the literature shows that prospective preschool teachers fail to build up positive attitudes toward mathematics and acquire sufficient knowledge of mathematics teaching during their student years (Kilpatrick et al., 2001). Furthermore, preschool teachers are reported to have low levels of mathematics knowledge and are afraid to teach mathematics (Ginsburg et al., 2008). From this point forth. it is important to identify the beliefs of prospective preschool teachers who are the future implementers of the program in mathematics education. Hence, the research aims at investigating prospective preschool teachers' beliefs about mathematics education.

\section{Preschool Teachers' Mathematics Education in Turkey}

The preschool teacher program in Turkey is started by choosing candidates who are graduates from any type of high school such as regular high school, Gymnasium (Anatolian high school), or a vocational high school (Anatolian teacher training high school or Child Development and Education Departments of vocational high schools). Then, the candidates should get an exam for entering a university.

Early Childhood Teacher Education is a four-year undergraduate program. There are three different types of courses which are content course (i.e., introduction to early childhood education, special teaching methods), teaching profession courses (i.e., school experiences, material development), and general education courses (i.e., educational philosophy, educational psychology) in the early childhood teacher education curriculum. In the content courses, prospective teachers take some courses about teaching in early childhood, drama in early childhood education or instructional technologies and material design, etc. One of the courses in the content is mathematics education in early childhood. Prospective teachers take this course in the fall term. The learning outcomes of this course are able to explain mathematical thinking in preschool education, recognize the importance of mathematics education in preschool, explain the development of mathematical concepts in preschool, explain how to design activities in preschool education, determine the roles of teachers in preschool education and investigate mathematics program in preschool education.

Since prospective teachers' beliefs about mathematics are affected by the courses in teacher education programs (Chai et al., 2009; Zakaria \& Musiran, 2010), the determination of the effects of these courses on their beliefs about mathematics education should be investigated. Furthermore, Raymond (1997) argues that the types of school of prospective preschool teachers are major variables because beliefs about mathematics are shaped through the individual's previous school experiences including the impact of teachers. Moreover, the types of schools that preschool prospective teachers will also be an important variable. This research 
Zeynep Bahar Erşen, Nimet Akin \& Fatih Karakuş, Investigation of Prospective Preschool Teachers'...

aims at examining the effects of the different variables on preschool prospective teachers' beliefs regarding teaching and learning mathematics.

Based on the literature review, a limited number of studies have been found examining the beliefs of pre-service/in-service preschool teachers on mathematics. For example, Zacharos et al. (2007) found that most of the Greek pre-service early childhood teachers interviewed had negative attitudes towards mathematics throughout their own school life. Moreover, Lee and Ginsburg (2007) explored teachers' beliefs about mathematics education for low-and middlesocioeconomic status children. While the teachers from a low-socioeconomic level determined that preschool mathematics was necessary and important to teach, the teachers of middle-socioeconomic level thought mathematics education was an important socialization tool in the preschool years. In the study of Anders and Rossbach (2015), 221 preschool teachers did not show negative attitudes towards mathematics and they showed some sensitivity to mathematics. Karataş et al. (2017) revealed that experienced preschool teachers tended to have positive views about mathematics teaching. Along with these studies, this research, which examines the effects of different variables on the beliefs of prospective preschool teachers, is believed to be able to contribute to the literature.

The problems of this study are presented:

1-What are the prospective pre-service teachers' beliefs about mathematics teaching and learning?

2. Does teacher education program have an effect on preschool prospective teachers' beliefs about mathematics teaching and learning?

3. Does the type of high school graduation have an effect on preschool prospective teachers' beliefs about mathematics teaching and learning?

\section{METHOD}

\section{Research Design}

The methodology of this research was a survey on the beliefs of prospective preschool teachers about mathematical teaching and learning. The survey includes asking a written questionnaire or a test of a large group to obtain data in order to determine specific characteristics of a group (Fraenkel et al., 2012). Surveys are used frequently in educational research to determine attitudes, beliefs or opinions of a group of people.

\section{Sample}


Data were collected from the 884 preschool prospective teachers at the end of the spring semester of the 2017-2018 academic year, in 3 weeks. To determine the preschool prospective teachers' beliefs about mathematics teaching and learning, prospective teachers in three state universities in the Aegean Region, Central Anatolia Region, and Black Sea Region in Turkey were selected. The aim of selecting prospective teachers from different regions was to ensure maximum diversity. Demographic characteristics of 884 preschool prospective teachers were presented in Table 1.

Table 1. Demographic characteristics of preschool prospective teachers

\begin{tabular}{|c|c|c|c|c|c|}
\hline \multirow{2}{*}{ Regions } & \multicolumn{4}{|c|}{ Grade Levels } & \multirow{2}{*}{ Total(N) } \\
\hline & Freshman (N) & Sophomore(N) & Junior (N) & Senior $(N)$ & \\
\hline Aegean Region & 101 & 43 & 65 & 73 & 282 \\
\hline Central Anatolia Region & 63 & 61 & 61 & 75 & 260 \\
\hline Black Sea Region & 84 & 78 & 90 & 90 & 342 \\
\hline TOTAL & 248 & 182 & 216 & 238 & 884 \\
\hline
\end{tabular}

The aim of selecting prospective teachers from four different levels is to determine the effects of the teacher education program on the prospective teachers' beliefs regarding mathematics teaching and learning.

\section{Data Collection Tool}

Data were collected by the "Mathematics, Education, Learning and Beliefs Scale (MELBS)", which was created in a national project [TUBITAK (Scientific and Technological Research Council of Turkey), project number is 110K249] and it was developed by Güven et al. (2013). This scale aims at examining beliefs of preschool teachers and prospective preschool teachers related to mathematics education and learning of mathematics. The scale, consisting of 32 items with six subscales, namely talent development and age-appropriateness of mathematical learning, learning mathematically, the nature of mathematics, teaching program, teaching and teachers' role, and teachers' qualification. The reliability coefficient of the scale for this study was .89. If Cronbach Alpha (a) value, which is the reliability coefficient is $0.80 \leq a \leq 1.00$, the scale is highly reliable and accepted (Tavşancll, 2006). However, the research on the validity of the scale was carried out by the researchers who developed the scale.

\section{Data Analysis}


Zeynep Bahar Erşen, Nimet Akin \& Fatih Karakuş, Investigation of Prospective Preschool Teachers'...

To examine prospective preschool teachers' beliefs about teaching and learning mathematics, both descriptive and inferential statistics were used. Before analyzing the data, the data normality test was conducted. To determine the normal distribution of the data, the coefficients of skewness and kurtosis were examined. If the ratio of the coefficient of skewness (kurtosis) to the coefficient of the standard error of skewness (kurtosis) is staying between -1,96 and +1.96 , the distribution of the data is considered normal (Field, 2009). It was determined that all the data were normally disturbed. The scores from each item in the belief scale were firstly analyzed descriptively with frequency and percentage. Moreover, to determine both the effect of preschool teacher education programs and grade levels on beliefs about mathematics teaching and learning, two-way ANOVA was used. Normal distribution and variance homogeneity, which are ANOVA's assumptions were also tested for each variable.

\section{RESULTS}

1. What are the prospective pre-service teachers' beliefs about mathematics education teaching and learning?

Table 2. Descriptive Analysis of MELBS Instrument

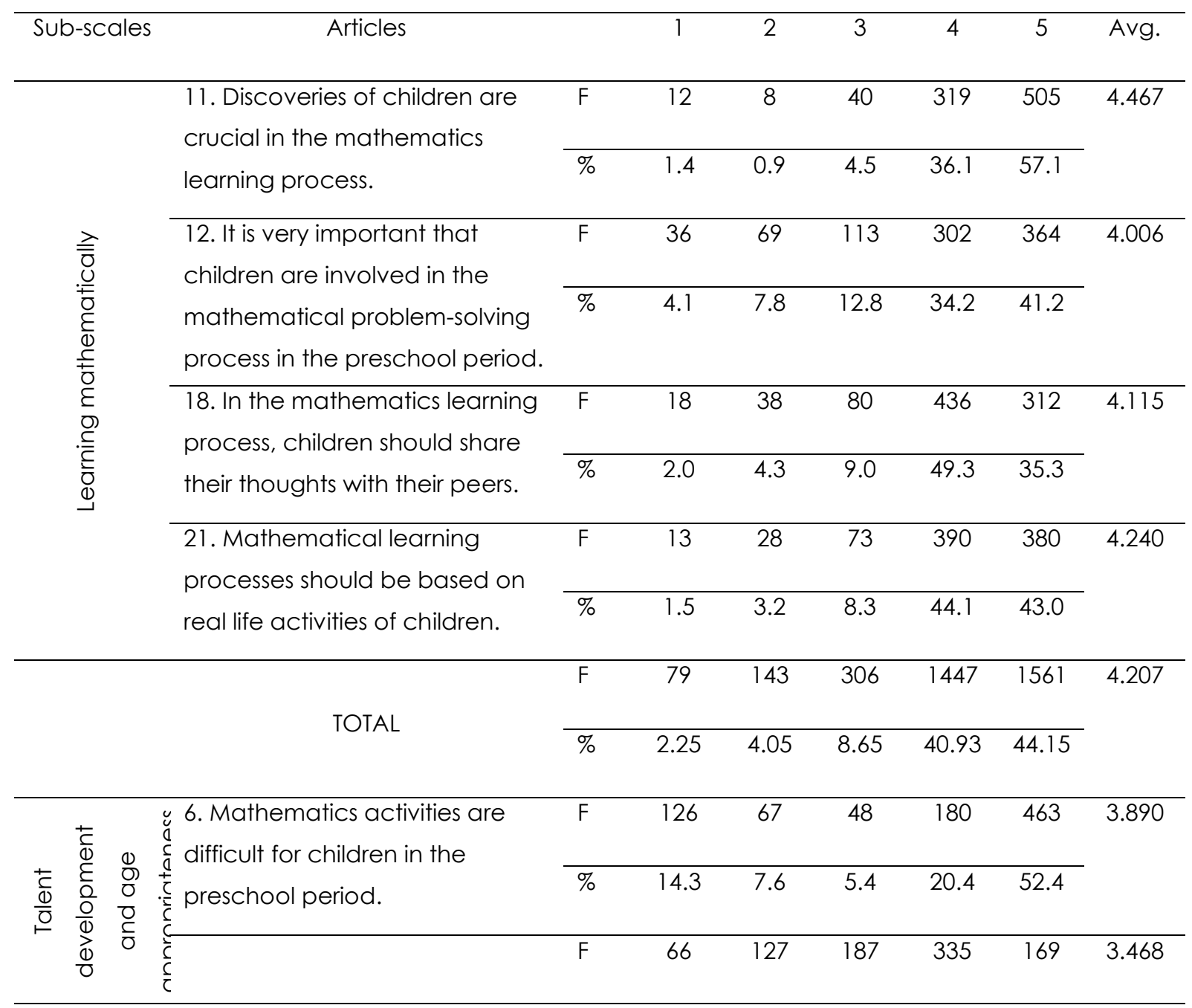




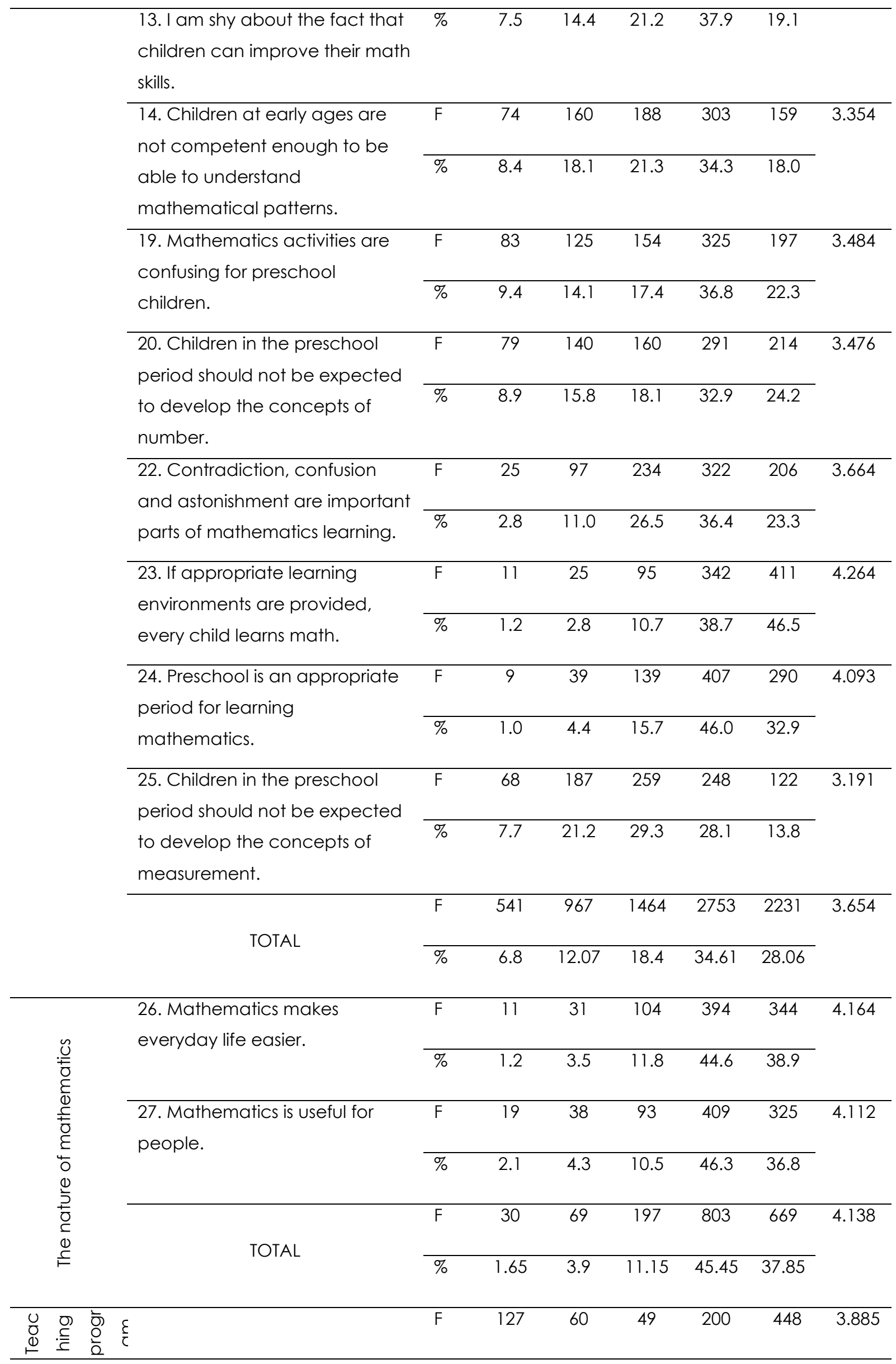


Zeynep Bahar Erşen, Nimet Akin \& Fatih Karakuş, Investigation of Prospective Preschool Teachers'...

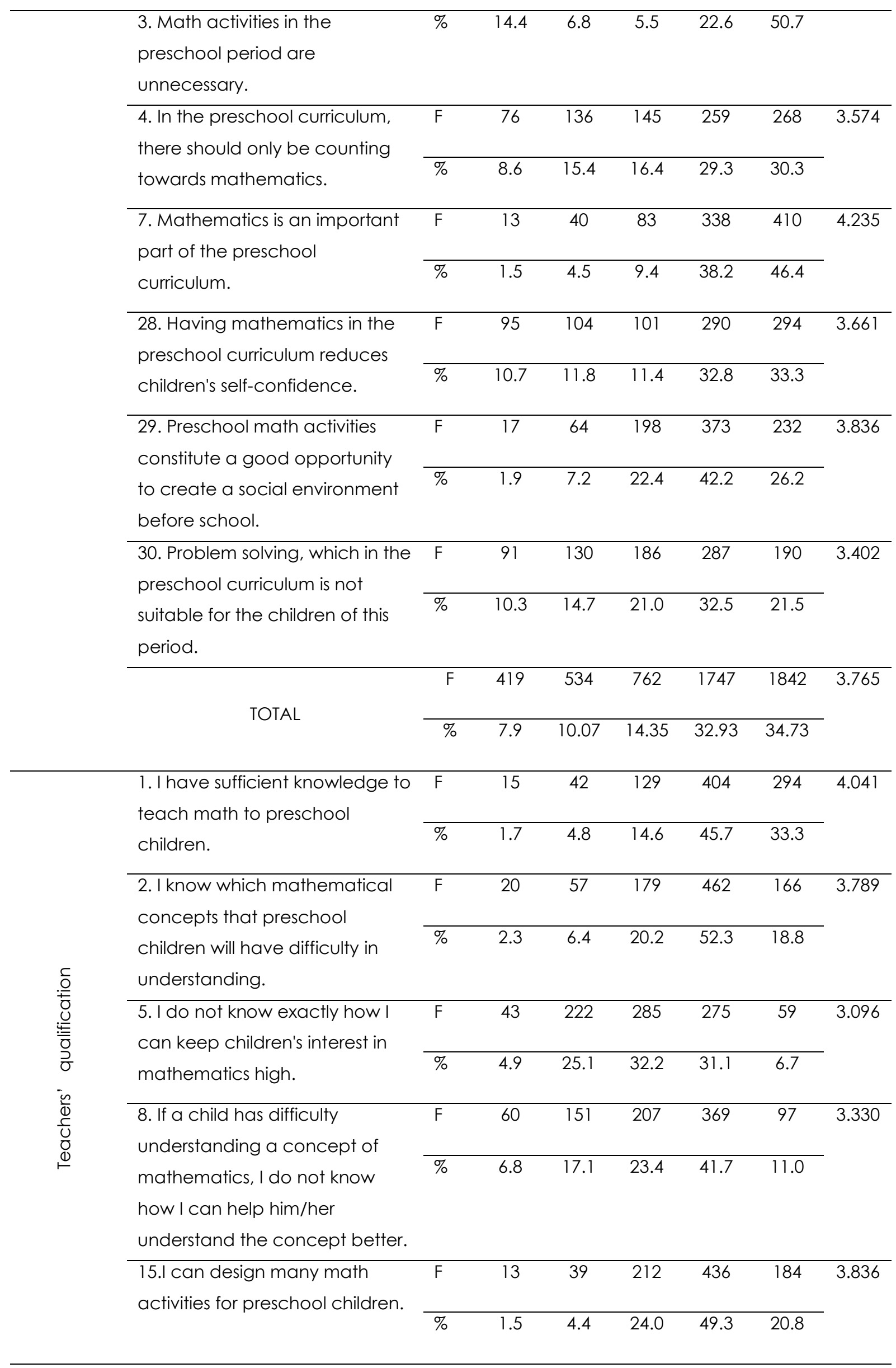


Mimbar Sekolah Dasar, Volume 8 Number 2 August 2021

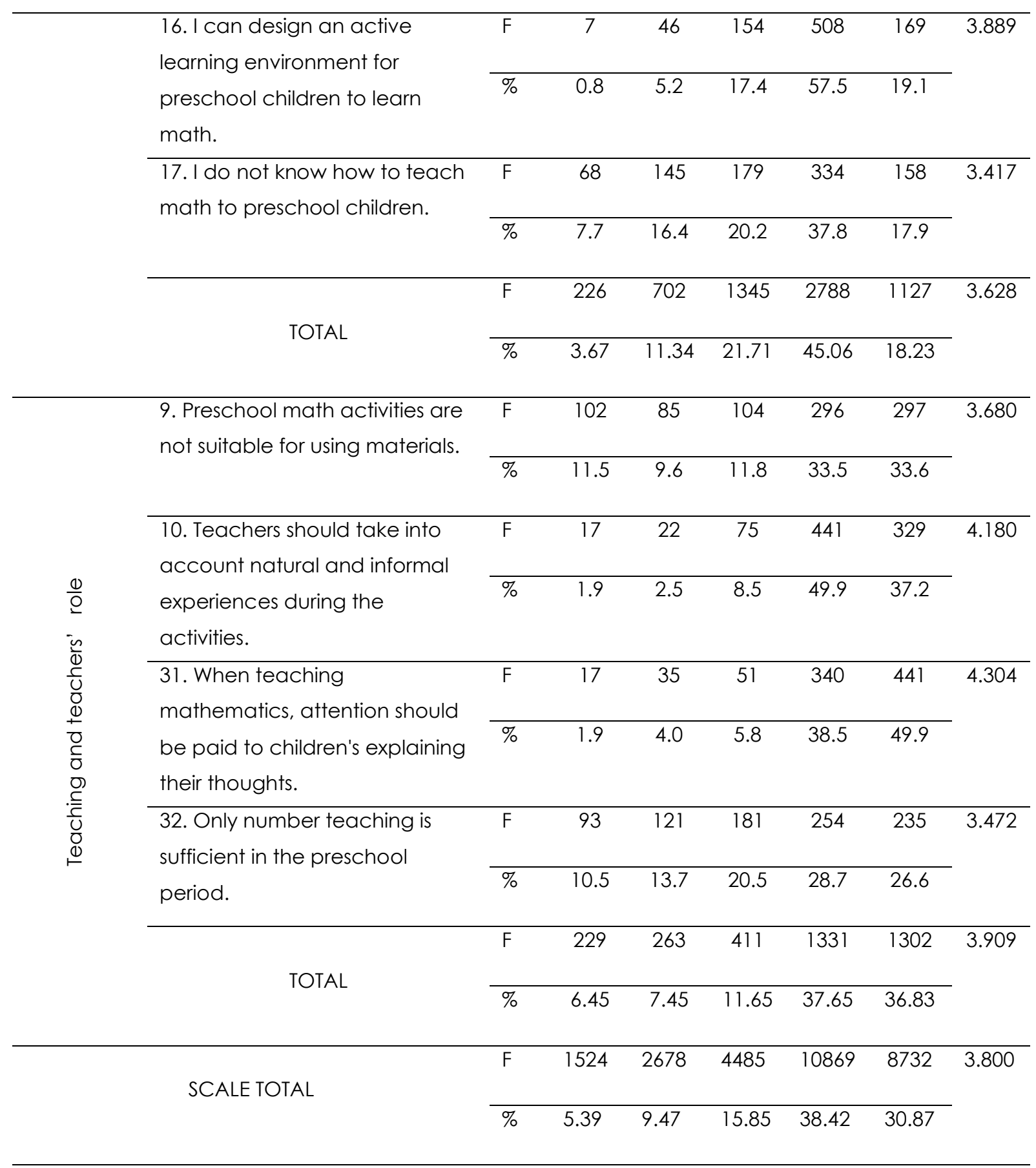

Table 2 shows that while prospective preschool teachers agreed with the 11 th and 21 st items in the "learning mathematically" sub-scale, they also agreed with the 12th and 18th items. While prospective teachers agreed with the $23 \mathrm{rd}$ item in the sub-scale of "Talent-development and age appropriateness of mathematical learning", they were undecided about the statements in the 14th and 25th items. However, they were found not to agree with the 6th, 13th, 19th, and 20th negative items in the same sub-scale and to agree with the 22nd item. Teacher candidates agreed with the items in the sub-scale of "the nature of mathematics." 
Zeynep Bahar Erşen, Nimet Akin \& Fatih Karakuş, Investigation of Prospective Preschool Teachers'...

In Table 2, prospective preschool teachers agreed with the 7th item in the "teaching program" sub-scale while they did not agree with the other negative items. In the "teachers' qualification" sub-scale, prospective teachers neither agreed or disagreed with their statements regarding the 5th and 8th items. As for the other items of the sub-scale, prospective preschool teachers agreed with the positive statements while they disagreed with the negative ones. Regarding the sub-scale of "teaching and teachers' role" while prospective preschool teachers agreed with the statement in the 31st item, they did not agree with the negative expressions in the 9th and 32nd items of the sub-scale and agree with the statement in the 10th item at a high level.

2. Do the prospective preschool teachers' beliefs regarding mathematics change significantly depending on the common effect of the class level and the type of school graduated from?

Table 3a. Descriptive statistical results of prospective teachers' opinions about the scale in accordance with the class level and the type of school graduated from

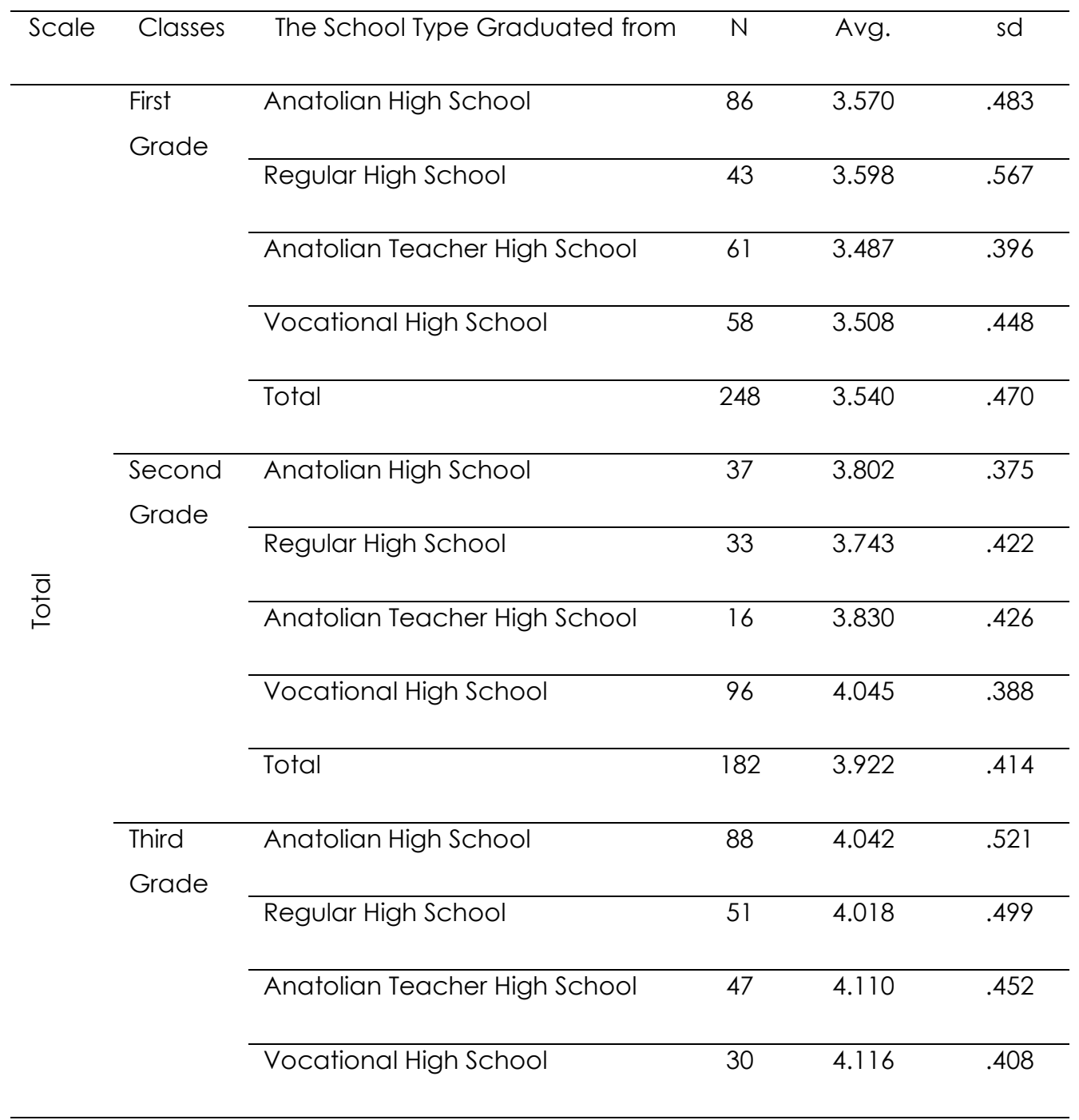


Mimbar Sekolah Dasar, Volume 8 Number 2 August 2021

\begin{tabular}{|c|c|c|c|c|}
\hline & Total & 216 & 4.062 & .486 \\
\hline \multirow{6}{*}{$\begin{array}{l}\text { Fourth } \\
\text { Grade }\end{array}$} & Anatolian High School & 84 & 3.718 & .537 \\
\hline & Reaular Hiah School & 44 & 3685 & 565 \\
\hline & keguidi חign sctioul & 44 & 0.000 & .505 \\
\hline & Anatolian Teacher High School & 36 & 3.799 & .589 \\
\hline & Vocational High School & 74 & 3.775 & .625 \\
\hline & Total & 238 & 3.742 & .576 \\
\hline \multirow[t]{5}{*}{ TOTAL } & Anatolian High School & 295 & 3.782 & .530 \\
\hline & Regular High School & 171 & 3.774 & .544 \\
\hline & Anatolian Teacher High School & 160 & 3.775 & .527 \\
\hline & Vocational High School & 258 & 3.855 & .530 \\
\hline & Total & 884 & 3.800 & .532 \\
\hline
\end{tabular}

Table 3b. Two-factor analysis of variance results of prospective teachers' opinions of the scale regarding the class level and the type of school graduated from

\begin{tabular}{|c|c|c|c|c|c|c|c|}
\hline Scale & $\begin{array}{c}\text { Source of the } \\
\text { Variance }\end{array}$ & $\begin{array}{l}\text { Sum of } \\
\text { Squares }\end{array}$ & sd & $\begin{array}{c}\text { Average of } \\
\text { Squares }\end{array}$ & $\mathrm{F}$ & $P$ & $\begin{array}{l}\text { Significant } \\
\text { Difference }\end{array}$ \\
\hline \multirow[t]{8}{*}{ Total } & Class level & 30.227 & 3 & 10.076 & 41.465 & .000 & $1-2,1-3,1-$ \\
\hline & The School & 1.121 & 3 & .374 & 1.537 & .203 & $\begin{array}{c}4,2-3,2-4 \\
3-4\end{array}$ \\
\hline & Type & & & & & & \\
\hline & Graduated & & & & & & \\
\hline & from & & & & & & \\
\hline & SD*MOOT & 3.011 & 9 & .335 & 1.377 & .194 & \\
\hline & Error & 210.915 & 868 & .243 & & & \\
\hline & Total & 13018.290 & 884 & & & & \\
\hline
\end{tabular}

Table 3b shows that the effect of the type of school graduated from at the level of first grade was not different from its effect at other class levels $[F(9,868)=1.377 ;(p>.05)]$. In addition, whereas the scores obtained did not differ significantly in accordance with the type of school graduated from $[F(3,868)=1.537 ;(p>.05)]$; the difference obtained in terms of class level was significant $[F(3,868)=41.465 ;(p<.05)]$. Therefore, when the average scores obtained from the 
Zeynep Bahar Erşen, Nimet Akin \& Fatih Karakuş, Investigation of Prospective Preschool Teachers'...

scale were compared with prospective first-grade teachers, they were in favor of the prospective second, third, and fourth-grade teachers. Compared to prospective secondgrade teachers, the average scores were in favor of prospective third-grade teachers and against prospective fourth-grade teachers. When the average scores of prospective third and fourth-grade teachers were compared, the difference was in favor of prospective teachers studying in the third grade.

Table 4a. Descriptive statistical results of prospective teachers' opinions regarding the "learning mathematically" sub-scale in accordance with the class level and the school type graduated from

\begin{tabular}{|c|c|c|c|c|c|}
\hline Sub-scale & Classes & The School Type Graduated from & $\mathrm{N}$ & Avg. & sd \\
\hline \multirow{19}{*}{ 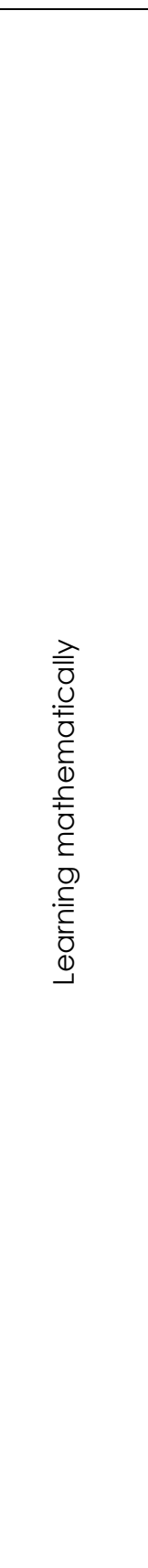 } & \multirow{5}{*}{$\begin{array}{l}\text { First } \\
\text { Grade }\end{array}$} & Anatolian High School & 86 & 4.093 & .627 \\
\hline & & Regular High School & 43 & 3.988 & .830 \\
\hline & & Anatolian Teacher High School & 61 & 4.016 & .557 \\
\hline & & Vocational High School & 58 & 4.344 & .473 \\
\hline & & Total & 248 & 4.115 & .630 \\
\hline & \multirow{5}{*}{$\begin{array}{l}\text { Second } \\
\text { Grade }\end{array}$} & Anatolian High School & 37 & 4.006 & .477 \\
\hline & & Regular High School & 33 & 4.129 & .586 \\
\hline & & Anatolian Teacher High School & 16 & 3.859 & .632 \\
\hline & & Vocational High School & 96 & 4.325 & .569 \\
\hline & & Total & 182 & 4.184 & .579 \\
\hline & \multirow{5}{*}{$\begin{array}{l}\text { Third } \\
\text { Grade }\end{array}$} & Anatolian High School & 88 & 4.261 & .691 \\
\hline & & Regular High School & 51 & 4.343 & .533 \\
\hline & & Anatolian Teacher High School & 47 & 4.255 & .569 \\
\hline & & Vocational High School & 30 & 4.367 & .559 \\
\hline & & Total & 216 & 4.294 & .610 \\
\hline & \multirow{4}{*}{$\begin{array}{l}\text { Fourth } \\
\text { Grade }\end{array}$} & Anatolian High School & 84 & 4.194 & .673 \\
\hline & & Regular High School & 44 & 4.233 & 620 \\
\hline & & Anatolian Teacher High School & 36 & 4.285 & .649 \\
\hline & & Vocational High School & 74 & 4.280 & .696 \\
\hline
\end{tabular}


Mimbar Sekolah Dasar, Volume 8 Number 2 August 2021

\begin{tabular}{llccc}
\hline & Total & 238 & 4.242 & .664 \\
\hline \multirow{2}{*}{ TOTAL } & Anatolian High School & 295 & 4.161 & .646 \\
\cline { 2 - 4 } & Regular High School & 171 & 4.184 & .660 \\
\cline { 2 - 4 } & Anatolian Teacher High School & 160 & 4.131 & .603 \\
& & & & \\
\hline & Vocational High School & 258 & 4.322 & .586 \\
& Total & & & \\
\hline
\end{tabular}

Table $\mathbf{4 b}$. Two-factor analysis of variance results of prospective teachers' opinions regarding the "learning mathematically" sub-scale in accordance with the class level and the school type graduated from

\begin{tabular}{|c|c|c|c|c|c|c|c|}
\hline Sub-scale & $\begin{array}{c}\text { Source of } \\
\text { the } \\
\text { Variance }\end{array}$ & $\begin{array}{l}\text { Sum of } \\
\text { Squares }\end{array}$ & sd & $\begin{array}{l}\text { Average } \\
\text { of Squares }\end{array}$ & $\mathrm{F}$ & $P$ & $\begin{array}{l}\text { Significant } \\
\text { Difference }\end{array}$ \\
\hline \multirow{8}{*}{$\begin{array}{c}\text { Learning } \\
\text { mathematically }\end{array}$} & Class level & 6.197 & 3 & 2.066 & 5.374 & .001 & $1-3$ \\
\hline & The School & 5.811 & 3 & 1.937 & 5.039 & .002 & AHS-VHS, \\
\hline & Type & & & & & & ATHS-VHS \\
\hline & Graduated & & & & & & \\
\hline & From & & & & & & \\
\hline & SD*MOOT & 3.761 & 9 & .418 & 1.087 & .370 & \\
\hline & Error & 333.667 & 868 & .384 & & & \\
\hline & Total & 15993.750 & 884 & & & & \\
\hline
\end{tabular}

Table $4 \mathrm{~b}$ shows that the effect of the school type graduated from on a class level was not different from its effect on other class levels $[F(9,868)=1.087 ;(p>.05)]$. In addition, while the scores obtained differed significantly in accordance with the type of school graduated from $[F(3,868)=5.039 ;(p<.05)]$, the difference obtained in terms of class level was also significant $[F(3,868)=5.374 ;(p<.05)]$. Therefore, the average scores of the prospective teachers in the third grade were significantly higher than those of prospective teachers in the first grade. Compared to Anatolian High School and Anatolian Teacher High School graduate prospective teachers, the scores of prospective teachers who graduated from vocational high school were significantly higher. 
Zeynep Bahar Erşen, Nimet Akin \& Fatih Karakuş, Investigation of Prospective Preschool Teachers'...

Table 5a. Descriptive statistical results of prospective teachers' opinions regarding the sub-scale of "talent development and age appropriateness of mathematical learning" in accordance with the class level and the type of school graduated from

\begin{tabular}{|c|c|c|c|c|c|}
\hline Sub-scale & Classes & The School Type Graduated from & $\mathrm{N}$ & Avg. & sd \\
\hline \multirow{27}{*}{ 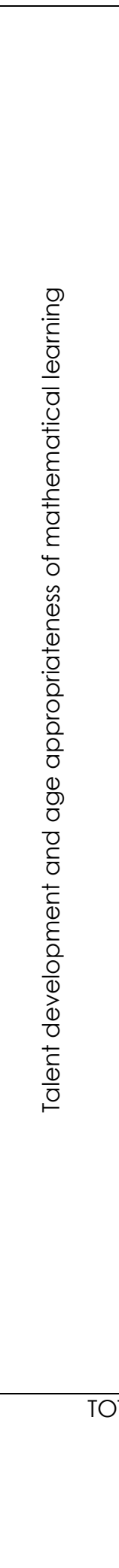 } & \multirow{6}{*}{$\begin{array}{l}\text { First } \\
\text { Grade }\end{array}$} & Anatolian High School & 86 & 3.382 & .676 \\
\hline & & & & & \\
\hline & & Regular Hign school & 43 & $3.4 / 8$ & .689 \\
\hline & & Anatolian Teacher High School & 61 & 3.317 & .567 \\
\hline & & Vocational High School & 58 & 3.190 & .640 \\
\hline & & Total & 248 & 3.338 & .648 \\
\hline & \multirow{6}{*}{$\begin{array}{l}\text { Second } \\
\text { Grade }\end{array}$} & Anatolian High School & 37 & 3.700 & .489 \\
\hline & & & 33 & 3620 & 180 \\
\hline & & & & & \\
\hline & & Anatolian Teacher High School & 16 & 3.799 & .463 \\
\hline & & Vocational High School & 96 & 3.924 & .482 \\
\hline & & Total & 182 & 3.812 & .495 \\
\hline & \multirow{6}{*}{$\begin{array}{l}\text { Third } \\
\text { Grade }\end{array}$} & Anatolian High School & 88 & 3.976 & .719 \\
\hline & & & & & \\
\hline & & Regular High School & 51 & 3.937 & .565 \\
\hline & & Anatolian Teacher High School & 47 & 4.076 & .529 \\
\hline & & Vocational High School & 30 & 4.011 & .520 \\
\hline & & Total & 216 & 3.993 & .618 \\
\hline & \multirow{6}{*}{$\begin{array}{l}\text { Fourth } \\
\text { Grade }\end{array}$} & Anatolian High School & 84 & 3.482 & .770 \\
\hline & & & & & \\
\hline & & Regular High School & 44 & 3.482 & 737 \\
\hline & & Anatolian Teacher High School & 36 & 3.614 & .771 \\
\hline & & Vocational High School & 74 & 3.650 & .804 \\
\hline & & Total & 238 & 3.554 & .774 \\
\hline & \multirow[t]{3}{*}{ TOTAL } & Anatolian High School & 295 & 3.628 & .736 \\
\hline & & Regular High School & 171 & 3.643 & .658 \\
\hline & & Anatolian Teacher High School & 160 & 3.655 & .672 \\
\hline
\end{tabular}




\begin{tabular}{lllll}
\hline Vocational High School & 258 & 3.690 & .693 \\
\cline { 2 - 5 } & Total & 884 & 3.654 & .697 \\
\end{tabular}

Table 5b. Two-factor analysis of variance results of prospective teachers' opinions regarding the sub-scale of "talent development and age appropriateness of mathematical learning" in accordance with the class level and the type of school graduated from

\begin{tabular}{|c|c|c|c|c|c|c|c|}
\hline Sub-scale & $\begin{array}{c}\text { Source of the } \\
\text { Variance }\end{array}$ & $\begin{array}{l}\text { Sum of } \\
\text { Squares }\end{array}$ & $\mathrm{sd}$ & $\begin{array}{l}\text { Average } \\
\text { of Squares }\end{array}$ & $\mathrm{F}$ & $P$ & $\begin{array}{l}\text { Significant } \\
\text { Difference }\end{array}$ \\
\hline 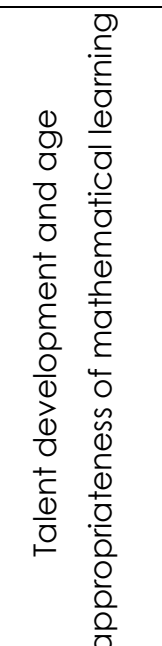 & $\begin{array}{l}\text { Class level } \\
\text { The School } \\
\text { Type } \\
\text { Graduated } \\
\text { from } \\
\text { SD*MOOT } \\
\text { Error } \\
\text { Total }\end{array}$ & $\begin{array}{c}6.218 \\
365.112 \\
12230.81 \\
5\end{array}$ & $\begin{array}{c}9 \\
868 \\
884\end{array}$ & $\begin{array}{l}.691 \\
.421\end{array}$ & $\begin{array}{c}38.182 \\
.616\end{array}$ & .605 & $\begin{array}{c}1-2,1-3,1- \\
4,2-3,2-4 \\
3-4\end{array}$ \\
\hline
\end{tabular}

Table $5 \mathrm{~b}$ shows that the effect of the type of school graduated from on one class level was not different from its effect on other class levels $[F(9,868)=1.642 ;(p>.05)]$. Besides, whereas the scores obtained did not differ significantly according to the type of school graduated from [F $(3,868)=0.616 ;(p>.05)]$, the difference obtained in terms of class level is significant $[F(3,868)$ $=38.182 ;(p<.05)]$. Therefore, when the average scores obtained from the scale were compared with prospective first-grade teachers, they were in favor of the prospective second, third, and fourth-grade teachers. Compared to the senior prospective teachers, the average scores were in favor of the prospective second-grade teachers. When the average scores of prospective third and fourth-grade teachers were compared, the difference was in favor of prospective teachers studying in the third grade.

Table 6a. Descriptive statistical results of prospective teachers' opinions regarding the "the nature of mathematics" sub-scale in accordance with the class level and the school type graduated from

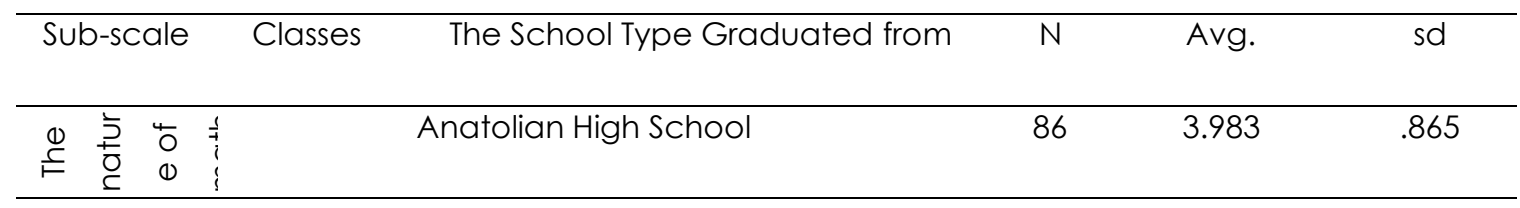


Zeynep Bahar Erşen, Nimet Akin \& Fatih Karakuş, Investigation of Prospective Preschool Teachers'...

\begin{tabular}{|c|c|c|c|c|}
\hline First & Regular High School & 43 & 4.081 & 1.029 \\
\hline \multirow[t]{3}{*}{ Grade } & Anatolian Teacher High School & 61 & 3.746 & .859 \\
\hline & Vocational High School & 58 & 4.259 & .572 \\
\hline & Total & 248 & 4.006 & .852 \\
\hline \multirow{5}{*}{$\begin{array}{l}\text { Second } \\
\text { Grade }\end{array}$} & Anatolian High School & 37 & 3.878 & .711 \\
\hline & Regular High School & 33 & 3.833 & .949 \\
\hline & Anatolian Teacher High School & 16 & 4.125 & .646 \\
\hline & Vocational High School & 96 & 4.323 & .641 \\
\hline & Total & 182 & 4.126 & .747 \\
\hline \multirow{6}{*}{$\begin{array}{l}\text { Third } \\
\text { Grade }\end{array}$} & Anatolian High School & 88 & 4.148 & .814 \\
\hline & Pegular Hiah Sohool & 51 & 177 & 786 \\
\hline & & & & \\
\hline & Anatolian Teacher High School & 47 & 4.223 & .800 \\
\hline & Vocational High School & 30 & 4.267 & 1.023 \\
\hline & Total & 216 & 4.188 & .832 \\
\hline \multirow{6}{*}{$\begin{array}{l}\text { Fourth } \\
\text { Grade }\end{array}$} & Anatolian High School & 84 & 4.286 & .749 \\
\hline & & & & \\
\hline & Regular High School & 44 & 4.171 & .655 \\
\hline & Anatolian Teacher High School & 36 & 4.347 & .664 \\
\hline & Vocational High School & 74 & 4.176 & .846 \\
\hline & Total & 238 & 4.240 & .752 \\
\hline \multirow[t]{5}{*}{ TOTAL } & Anatolian High School & 295 & 4.105 & .809 \\
\hline & Regular High School & 171 & 4.085 & .859 \\
\hline & Anatolian Teacher High School & 160 & 4.059 & .815 \\
\hline & Vocational High School & 258 & 4.260 & .741 \\
\hline & Total & 884 & 4.138 & .804 \\
\hline
\end{tabular}

Table 6b. Two-factor analysis of variance results of prospective teachers' opinions regarding the "the nature of mathematics" sub-scale in accordance with the class level and the school type graduated from 
Mimbar Sekolah Dasar, Volume 8 Number 2 August 2021

\begin{tabular}{|c|c|c|c|c|c|c|c|}
\hline Sub-scale & $\begin{array}{c}\text { Source of the } \\
\text { Variance }\end{array}$ & $\begin{array}{l}\text { Sum of } \\
\text { Squares }\end{array}$ & sd & $\begin{array}{c}\text { Average of } \\
\text { Squares }\end{array}$ & $\mathrm{F}$ & $P$ & $\begin{array}{l}\text { Significant } \\
\text { Difference }\end{array}$ \\
\hline \multirow{6}{*}{$\begin{array}{l}\text { The nature of } \\
\text { mathematics }\end{array}$} & Class level & 7.760 & 3 & 2.587 & 4.124 & .006 & $1-4$ \\
\hline & The School Type & 4.973 & 3 & 1.658 & 2.643 & .048 & AHS-VHS, \\
\hline & Graduated from & & & & & & RHS-VHS, \\
\hline & SD*MOOT & 12.507 & 9 & 1.390 & 2.216 & .019 & ATHS-VHS \\
\hline & Error & 544.399 & 868 & .627 & & & \\
\hline & Total & 15707.000 & 884 & & & & \\
\hline
\end{tabular}

Table $6 \mathrm{~b}$ shows the effect of the type of school graduated from on a class level was different from its effect on other class levels $[F(9,868)=2.216 ;(p<.05)]$. In addition, while the scores obtained differed significantly in accordance with the type of school graduated from [F (3, $868)=2,643 ;(p<.05)]$, the difference obtained in terms of class level was also significant [ $F(3$, $868)=4,124 ;(p<.05)]$. Therefore, the average scores of the prospective teachers in the fourth grade were significantly higher than those of prospective teachers in the first grade. Compared to Anatolian High School and Anatolian Teacher High School graduate prospective teachers, the scores of prospective teachers who graduated from vocational high school were significantly higher.

Table 7a. Descriptive statistical results of prospective teachers' opinions regarding the "teaching program" sub-scale in accordance with the class level and the school type graduated from

\begin{tabular}{|c|c|c|c|c|c|}
\hline Sub-scale & Classes & The School Type Graduated from & $\mathrm{N}$ & Avg. & sd \\
\hline \multirow{11}{*}{$\begin{array}{l}\varepsilon \\
0 \\
\overline{0} \\
0 \\
0 \\
0 \\
0 \\
. \frac{1}{D} \\
\frac{1}{0} \\
0 \\
\varrho\end{array}$} & \multirow{6}{*}{$\begin{array}{l}\text { First } \\
\text { Grade }\end{array}$} & Anatolian High School & 86 & 3.374 & .778 \\
\hline & & & & & \\
\hline & & Regular High School & 43 & 3.442 & .739 \\
\hline & & Anatolian Teacher High School & 61 & 3.336 & .656 \\
\hline & & Vocational High School & 58 & 3.152 & .732 \\
\hline & & Total & 248 & 3.325 & .735 \\
\hline & \multirow{5}{*}{$\begin{array}{l}\text { Second } \\
\text { Grade }\end{array}$} & Anatolian High School & 37 & 3.842 & .551 \\
\hline & & Porlular Hiah sabon & & 3838 & $60 ?$ \\
\hline & & Regular HIgn scnool & 33 & 3.838 & .692 \\
\hline & & Anatolian Teacher High School & 16 & 3.927 & .683 \\
\hline & & Vocational High School & 96 & 4.179 & .540 \\
\hline
\end{tabular}


Zeynep Bahar Erşen, Nimet Akin \& Fatih Karakuş, Investigation of Prospective Preschool Teachers'...

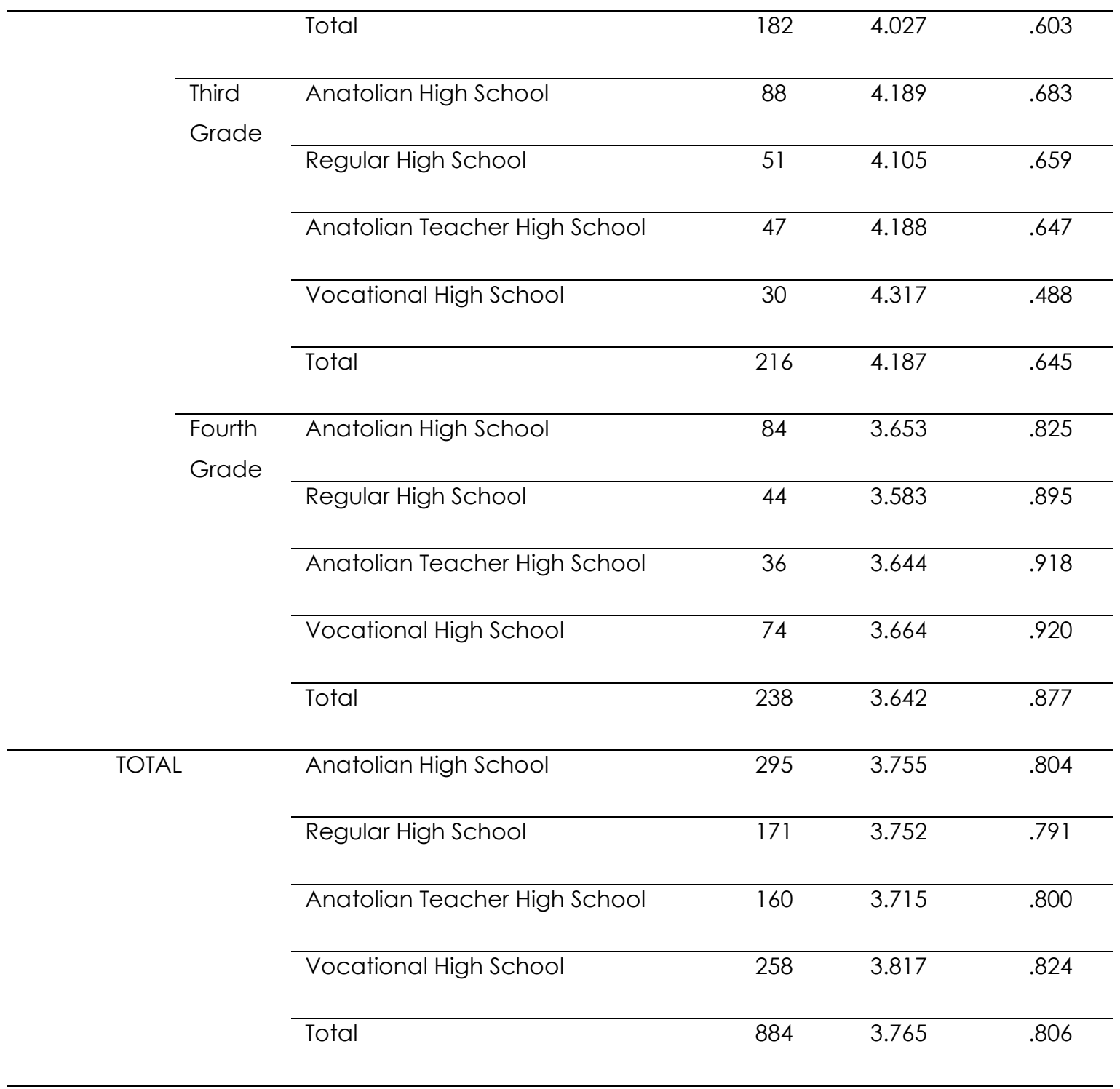

Table 7b. Two-factor analysis of variance results of prospective teachers' opinions regarding the "teaching program" sub-scale in accordance with the class level and the school type graduated from

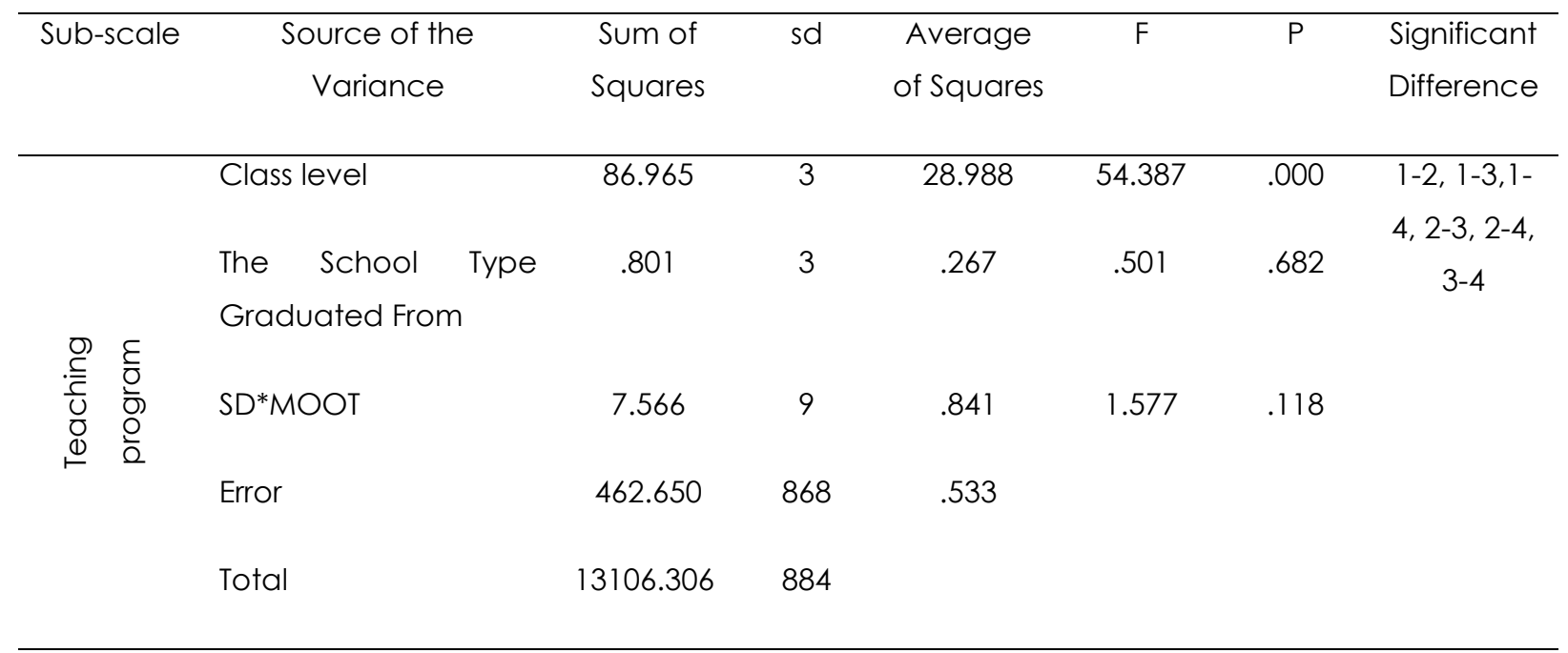


Table 7b shows that the effect of the school type graduated from on a class level was not different from its effect on other class levels $[F(9,868)=1.577 ;(p>.05)]$. Besides, whereas the scores obtained did not differ significantly in accordance with the type of school graduated from $[F(3,868)=0.501 ;(p>.05)]$, the difference obtained in terms of class level was significant $[F(3,868)=54.387 ;(p<.05)]$. Therefore, when the average scores obtained from the scale were compared with prospective first-grade teachers, they were in favor of the prospective second, third and fourth-grade teachers. Compared with the senior teacher candidates, the average scores were in favor of prospective preschool teachers studying in the 2nd and 3rd grades in this sub-scale.

Table 8a. Descriptive statistical results of prospective teachers' opinions regarding the "teachers' qualification" sub-scale in accordance with the class level and the school type graduated from

\begin{tabular}{|c|c|c|c|c|c|}
\hline Sub-scale & Classes & The School Type Graduated from & $\mathrm{N}$ & Avg. & Sd \\
\hline \multirow{19}{*}{ 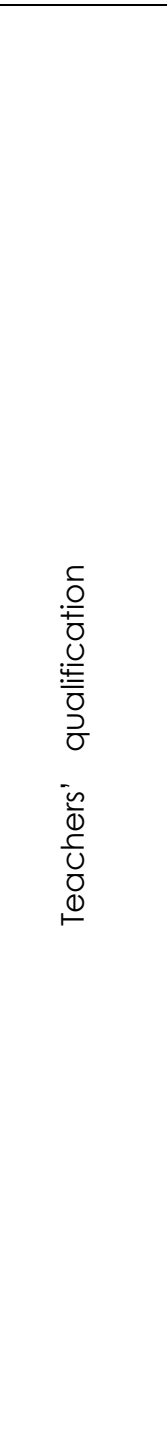 } & \multirow{6}{*}{$\begin{array}{l}\text { First } \\
\text { Grade }\end{array}$} & Anatolian High School & 86 & 3.513 & .546 \\
\hline & & & & 3110 & $6 \cap 7$ \\
\hline & & & & & \\
\hline & & Anatolian Teacher High School & 61 & 3.464 & .474 \\
\hline & & Vocational High School & 58 & 3.535 & .500 \\
\hline & & Total & 248 & 3.495 & .527 \\
\hline & \multirow{6}{*}{$\begin{array}{l}\text { Second } \\
\text { Grade }\end{array}$} & Anatolian High School & 37 & 3.645 & .428 \\
\hline & & & & & \\
\hline & & Regular High School & 33 & 3.489 & .624 \\
\hline & & Anatolian Teacher High School & 16 & 3.589 & .472 \\
\hline & & Vocational High School & 96 & 3.694 & .581 \\
\hline & & Total & 182 & 3.637 & .554 \\
\hline & \multirow{7}{*}{$\begin{array}{l}\text { Third } \\
\text { Grade }\end{array}$} & Anatolian High School & 88 & 3.774 & .534 \\
\hline & & & & & \\
\hline & & Regular High School & 51 & 3.796 & .649 \\
\hline & & Anatolian Teacher High School & 47 & 3.930 & .455 \\
\hline & & Vocational High School & 30 & 3.791 & .440 \\
\hline & & Total & 216 & 3.816 & .536 \\
\hline & & Anatolian High School & 84 & 3.590 & .591 \\
\hline
\end{tabular}


Zeynep Bahar Erşen, Nimet Akin \& Fatih Karakuş, Investigation of Prospective Preschool Teachers'...

\begin{tabular}{|c|c|c|c|c|}
\hline Fourth & Regular High School & 44 & 3.542 & .494 \\
\hline \multirow[t]{4}{*}{ Grade } & & & & \\
\hline & Anatolian Teacher High School & 36 & 3.650 & .572 \\
\hline & Vocational High School & 74 & 3.591 & .629 \\
\hline & Total & 238 & 3.591 & .581 \\
\hline \multirow[t]{5}{*}{ TOTAL } & Anatolian High School & 295 & 3.630 & .550 \\
\hline & Regular High School & 171 & 3.584 & .608 \\
\hline & Anatolian Teacher High School & 160 & 3.655 & .524 \\
\hline & Vocational High School & 258 & 3.640 & .567 \\
\hline & Total & 884 & 3.628 & .562 \\
\hline
\end{tabular}

Table 8b. Two-factor analysis of variance results of prospective teachers' opinions regarding the "Teachers' qualification" sub-scale in accordance with the class level and the school type graduated from

\begin{tabular}{|c|c|c|c|c|c|c|c|}
\hline $\begin{array}{l}\text { Sub- } \\
\text { scale }\end{array}$ & $\begin{array}{c}\text { Source of the } \\
\text { Variance }\end{array}$ & $\begin{array}{l}\text { Sum of } \\
\text { Squares }\end{array}$ & sd & $\begin{array}{l}\text { Average of } \\
\text { Squares }\end{array}$ & $\mathrm{F}$ & $P$ & $\begin{array}{l}\text { Significant } \\
\text { Difference }\end{array}$ \\
\hline \multirow{5}{*}{ 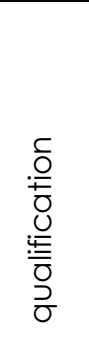 } & Class level & 11.800 & 3 & 3.933 & 12.940 & .000 & \multirow{8}{*}{$\begin{array}{c}1-3,2-3,3- \\
4\end{array}$} \\
\hline & The School & .828 & 3 & .276 & .908 & .437 & \\
\hline & Type & & & & & & \\
\hline & Graduated & & & & & & \\
\hline & from & & & & & & \\
\hline \multirow{3}{*}{ 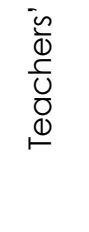 } & SD*MOOT & 1.427 & 9 & .159 & .522 & .859 & \\
\hline & Error & 263.853 & 868 & .304 & & & \\
\hline & Total & 11916.122 & 884 & & & & \\
\hline
\end{tabular}

Table $8 \mathrm{~b}$ shows the effect of the type of school graduated from on a class level was not different from its effect on other class levels $[F(9,868)=0.522 ;(p>.05)]$. Besides, whereas the scores obtained did not differ significantly in accordance with the type of school graduated from $[F(3,868)=0.908 ;(p>.05)]$, the difference obtained in terms of class level was significant $[F(3,868)=12.940 ;(p<.05)]$. Therefore, when the average scores obtained from the scale were compared with prospective first-grade teachers, they were in favor of the prospective second and third-grade teachers. Compared with the senior teacher prospective teachers, 
the average scores were in favor of prospective preschool teachers studying in the 3rd grade in this sub-scale.

Table 9a. Descriptive statistical results of prospective teachers' opinions regarding the "teaching and teachers' role" sub-scale in accordance with the class level and the school type graduated from

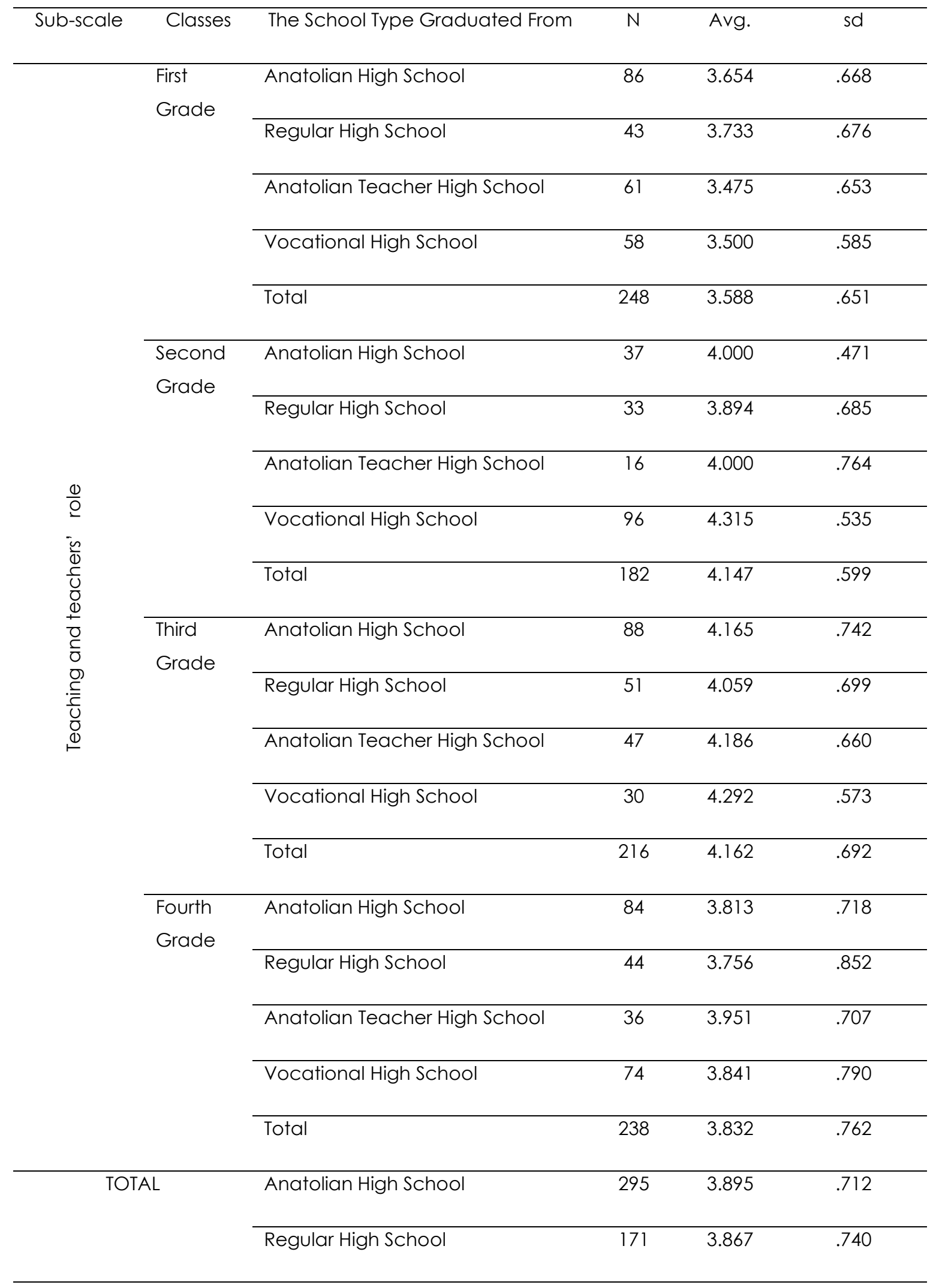


Zeynep Bahar Erşen, Nimet Akin \& Fatih Karakuş, Investigation of Prospective Preschool Teachers'...

\begin{tabular}{lllll}
\hline & Anatolian Teacher High School & 160 & 3.844 & .737 \\
\cline { 2 - 4 } & & & \\
\hline & & 258 & 3.993 & .711 \\
\cline { 2 - 4 } & & & 3.909 & .723
\end{tabular}

Table 9b. Two-factor analysis of variance results of prospective teachers' opinions regarding the "teaching and teachers' role " sub-scale in accordance with the class level and the school type graduated from

\begin{tabular}{|c|c|c|c|c|c|c|c|}
\hline $\begin{array}{l}\text { Sub- } \\
\text { scale }\end{array}$ & $\begin{array}{c}\text { Source of the } \\
\text { Variance }\end{array}$ & $\begin{array}{l}\text { Sum of } \\
\text { Squares }\end{array}$ & $\mathrm{sd}$ & $\begin{array}{c}\text { Average of } \\
\text { Squares }\end{array}$ & $F$ & $P$ & $\begin{array}{l}\text { Significant } \\
\text { Difference }\end{array}$ \\
\hline \multirow{8}{*}{ 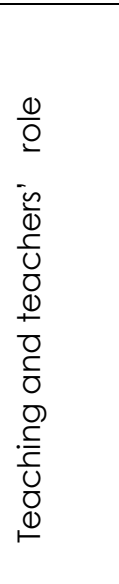 } & Class level & 39.858 & 3 & 13.286 & 28.837 & .000 & \multirow{8}{*}{$\begin{array}{c}\begin{array}{c}1-2,1-3,1- \\
4,2-3,2-4 \\
3-4\end{array} \\
\end{array}$} \\
\hline & School & 1.632 & 3 & .544 & 1.181 & .316 & \\
\hline & Type & & & & & & \\
\hline & Graduated & & & & & & \\
\hline & from & & & & & & \\
\hline & SD*MOOT & 8.528 & 9 & .948 & 2.057 & .031 & \\
\hline & Error & 399.916 & 868 & .461 & & & \\
\hline & Total & 13968.750 & 884 & & & & \\
\hline
\end{tabular}

Table $9 \mathrm{~b}$ shows that the effect of the school graduated from on a class level differed from its effect on other class levels $[F(9,868)=2.057 ;(p<.05)]$. Besides, while the scores obtained did not differ significantly in accordance with the type of school graduated from $[F(3,868)=1.181$; $(p>.05)]$, the difference obtained in terms of class level was significant $[F(3,868)=54,387$; $(p$ $<.05)]$. Therefore, when the average scores were compared with prospective first-grade teachers, they were in favor of the prospective second, third and fourth-grade teachers. When compared with senior prospective teachers, the average scores were in favor of prospective preschool teachers studying in second and third grades.

\section{DISCUSSION}

The research results revealed that the prospective preschool teachers had high levels of positive beliefs on mathematics education based on the average scores of the overall scale and its sub-scales. It may be suggested that their strong beliefs on mathematics education were reflected positively in their future teaching lives. According to Zacharos et al. (2007), teachers holding negative beliefs about mathematics throughout their education lives did not like the process of teaching mathematics. Strong beliefs about mathematics education in prospective preschool teachers showed that, compared to a traditional approach, such 
teacher candidates had a constructivist approach in guiding the student through self-learning. This was supported by the scale items such as "discoveries of children are crucial in the mathematics learning process" or "when appropriate learning environments are provided, every child learns mathematics" or "when teaching mathematics, attention should be paid to allow children for explaining their thoughts". Furthermore, the study conducted by Kayan, et al. (2013) revealed that prospective teachers had constructivist beliefs. Considering that a constructivist-based education system has been realized in Turkey since 2005, the obtained results may have occurred as expected.

The results of the two-way ANOVA to examine the average scores from the overall scale reveal that the prospective preschool teachers' beliefs on mathematics education differed significantly in graduation compared to the first year in the school of education. Furthermore, there were also significant differences in the mathematical beliefs of prospective preschool teachers between those in intermediate grade levels and the ones in the fourth grade. Compared to prospective preschool teachers in other grade levels, the average scores of those in the third grade were significantly higher when training about teaching mathematics was received. This finding indicates that the preschool teacher education curriculum acting on prospective preschool teachers' beliefs about mathematics were similar to the results of the studies conducted on prospective primary school mathematics teachers despite the differences in the study samples throughout the study (Ambrose, 2004; Dede and Karakuş, 2014; Kayan et al., 2013; Swars et al., 2009; Wilkins \& Brand, 2004).

In this research, the average scores obtained from the "talent development and ageappropriateness of mathematical learning", "teaching program" and "teaching and teachers' role" sub-scales were in favor of prospective preschool teachers in the second, third, and fourth grades compared to the scores obtained by those in the first grade. Furthermore, compared to senior prospective teachers, the average scores were in favor of prospective preschool teachers in the second and third grades. In the "learning mathematically" sub-scale, there was a significant difference in average scores in favor of prospective preschool teachers in the third grade compared to those in the first grade. In the "the nature of mathematics" sub-scale, the average scores were significantly different in favor of the senior prospective preschool teachers compared to those in the first grades. In the "teachers' qualification" sub-scale, there was a significant difference in favor of the average scores of prospective teachers in the third grade compared to those in other grade levels. This finding was likely influenced by prospective preschool teachers taking a mathematics education course and then practicing microteaching in third grade. Certainty, the literature review shows that teaching practices in the curriculum of schools of education were acted on prospective teachers' beliefs about mathematics (Gill et al., 2004; Tatto et al., 2008; Vacc and Bright, 1999). 
Zeynep Bahar Erşen, Nimet Akin \& Fatih Karakuş, Investigation of Prospective Preschool Teachers'...

Another variable thought to act on prospective preschool teachers' beliefs about mathematic education in the research was the type of high school of graduation. Based on the results of the two-way ANOVA, a significant difference in the average scores of prospective preschool teachers was found only in "learning mathematically" and "the nature of mathematics" subscales in favor of vocational high school graduates. In other words, the prospective preschool teachers who graduated from vocational high schools had more positive beliefs on the nature of mathematics. The research conducted by Karataş et al. (2017) found that a significant difference was in the average scores of the "the nature of mathematics" sub-scale by the school type of graduation. Moreover; Maasepp and Bobis (2014) also found that university graduate teachers' opinions about mathematics were more positive compared to teachers who graduated from other types of schools. However, those results failed to achieve statistical significance.

This research also found an increase in the average sub-scale scores, excluding the "the nature of mathematics", starting from the first grade to the third grade. However, the scores decreased in the fourth grade. The researchers have assumed that such increases would perpetuate to the senior year. This finding indicates that working through prospective teachers' beliefs was not a possibility but a necessity for teacher training programs (Swars et al., 2009). The decrease in average scores may be related to the negative experiences of prospective teachers in the senior year. Therefore, difficulties, workload, and working conditions experienced in the first year of the occupation might act on teachers' beliefs negatively (Cady, Meier \& Lubinski, 2006; Felbrich, Müller \& Blömeke, 2008).

\section{Conclusion}

In this research, prospective preschool teachers' beliefs about mathematics education and the effects of the grade level and the school type of graduation on such beliefs were investigated. While it is gratifying in the name of training programs that prospective teachers' beliefs about mathematics education are in a positive trend, the research may need to be repeated on different study samples. Furthermore, the effects of various other variables on prospective preschool teachers' beliefs about mathematics education may be examined.

In addition, prospective preschool teachers' beliefs about mathematics education were highly positive. The reflections of the study results on the actual education practices of the study participants may be investigated whether their mathematics teaching practices are parallel to their beliefs. Moreover, the decrease in the average MELBS scores of prospective preschool teachers in the senior year may be examined in depth through qualitative studies.

The research may be repeated with the same participants after graduation. Thus, trends in modifications of prospective teachers' beliefs about mathematics can be found out.

\section{REFERENCES}


Ambrose, R. (2004). Initiating change in prospective elementary school teachers' orientations to mathematics teaching by building on beliefs. Journal of Mathematics Teacher Education, 7, 91-119.

Ambrose, R., Clement, L., Philipp, R., \& Chauvot, J. (2004). Assessing prospective elementary school teachers' beliefs about mathematics and mathematics learning: rationale and development of a constructed-response-format beliefs survey. School Science and Mathematics, $104(2), 56-69$.

Anders, Y., \& Rossbach, H. G. (2015). Preschool teachers' sensitivity to mathematics in children's play: the influence of math-related school experiences, emotional attitudes, and pedagogical beliefs. Journal of Research in Childhood Education, 29(3), 305-322, doi: $10.1080 / 02568543.2015 .1040564$

Baki, A., \& Hacısalihoğlu-Karadeniz, M. (2013). Okul öncesi eğitim programının matematik uygulama sürecinden yansımalar [Reflections from in-class mathematics applications in pre-school educational curriculum] Kastamonu Eğitim Dergisi, 21 (2), 619-636.

Barkatsas, A., \& Malone, J. (2005). A typology of mathematics teachers beliefs about teaching and learning mathematics and instructional practices. Mathematics Education Research Journal, 17(2), 69-90.

Cady, J., Meier, S. L., \& Lubinski, C. A. (2006). Developing mathematics teachers: The transition from preservice to experienced teacher. Journal of Educational Research, 99(5), 295305. doi:10.3200/JOER.99.5.295-306

Cady, J. A., \& Rearden, K. (2007). Pre-service teachers' beliefs about knowledge, mathematics, and science. School Science and Mathematics, 107(6), 237-245. doi:10.1111/j.19498594.2007.tb 18285.x

Carter, G., \& Norwood, K. S. (1997). The relationship between teacher and student beliefs about mathematics. School Science and Mathematics, 97(2), 62-66.

Chai, S. C., Teo, T. \& Lee, C. B. (2009). The change in epistemological beliefs and beliefs about teaching and learning: a study among pre-service teachers. Asia-Pacific Journal of Teacher Education, 37(4), 351-362.

Cohen, L., Manion, L., \& Morrison, K. (2000). Research methods in education (5th ed.). London: Routledge Falmer.

Dede, Y., \& Karakuş, F. (2014). Matematik öğretmeni adaylarının matematiğe yönelik inançları üzerinde öğretmen eğitimi programlarının etkisi [The effect of teacher training programs 
Zeynep Bahar Erşen, Nimet Akin \& Fatih Karakuş, Investigation of Prospective Preschool Teachers'...

on pre-service mathematics teachers' beliefs towards mathematics]. Kuram ve Uygulamada Eğitim Bilimleri [Educational Sciences: Theory \& Practice], 14 (2), 791-813.

Duru, A., \& Göl, R. (2016). Öğretmen adaylarının matematik, matematik öğretimi ve matematik öğrenmeye ilişkin inançları [Beliefs of prospective teachers about mathematics, mathematics teaching and mathematics learning]. Adlyaman Üniversitesi Eğitim Bilimleri Dergisi [Adıyaman University Journal of Educational Sciences], 6(2), 255-282.

Ernest, P. (1989). The knowledge, beliefs, and attitudes of the mathematics teacher: A model. Journal of Education for Teaching, 15, 13-33.

Felbrich, A., Müller, C., \& Blömeke, S. (2008). Epistemological beliefs concerning the nature of mathematics among teacher educators and teacher education students in mathematics. ZDM-The International Journal of Mathematics Education, 40(5), 763-776.

Gill, M. G., Ashton, P. T., \& Algina, J. (2004). Changing pre-service teachers' epistemological beliefs about teaching and learning in mathematics: An intervention study. Contemporary Educational Psychology, 29, 164-185.

Ginsburg, H. P., Lee, J. S., \& Boyd, J. S. (2008). Mathematics education for young children: What it is and how to promote it. Social Policy Report of the Society for Research in Child Development, 22, 3-23.

Gürkan, T. (1981). Türkiye'de okul öncesi eğitim programlarının değerlendirilmesi ve geliştirilmesi [Evaluation and development of pre-school education programs in Turkey]. (Doktora Tezi).

Güven, B., Karataş, İ., Öztürk, Y., Arslan, S., \& Gürsoy, K. (2013). Okul öncesi öğretmenlerinin ve öğretmen adaylarının okul öncesi matematik eğitimine ilişkin inançların belirlenmesine yönelik bir ölçek geliştirme çalışması [A study of scale development on determination of pre-service and in-service teachers' beliefs about pre-school mathematics education]. ilköğretim Online [Elementary Education Online], 12 (4), 969-980.

Güven, B., Öztürk, Y., Karataş, İ., Arslan, S. \& Şahin, F. (2012). Okul öncesi öğretmenlerinin matematik öğrenme ve öğretmeye yönelik inançlarının sınıf ortamına yansımaları [Reflections of preschool teachers' beliefs about learning and teaching mathematics on the classroom environment], X. Fen Bilimleri ve Matematik Eğitimi Kongresi, 27-30 Haziran 2012, Niğde.

Karakuş, H. (2015). Okul öncesi öğretmenlerinin matematiksel gelişimine ilişkin inanışları ile çocukların matematik kavram kazanımları arasındaki ilişkinin incelenmesi [The investigation of relationship between preschool teachers' beliefs regarding mathematical development and children's acquisition of mathematics 
concepts] (Yayımlanmamış Yüksek Lisans Tezi) [Unpublished master's thesis]. Hacettepe Üniversitesi, İlköğretim Anabilim Dalı, Okul Öncesi Eğitimi Bilim Dalı, Ankara.

Karataş, İ., Güven, B., Öztürk, Y., Arslan, S., \& Gürsoy, K. (2017). Investigation of pre-school teachers' beliefs about mathematics education in terms of their experience and structure of their education. EURASIA Journal of Mathematics Science and Technology Education, 13(3), 673-689. doi:10.12973/eurasia.2017.00638a

Kayan, R., Haser, Ç., \& Işıksal-Bostan, M. (2013). Matematik öğretmen adaylarının matematiğin doğası, öğretimi ve öğrenimi hakkındaki inanışları [Preservice Mathematics Teachers' Beliefs about the Nature of Teaching and Learning Mathematics]. Eğitim ve Bilim [Education and Science], 38(167), 179-195.

Kilpatrick, J., Swafford, J., \& Findell, B. (2001). Adding it up: Helping children learn mathematics. Washington, DC: National Academy Press.

Kul, Ü. (2017). Matematik ve sınıf öğretmeni adaylarının matematiğe yönelik inanışlarının incelenmesi [Analysis of pre-service mathematics and elementary school teachers' beliefs towards mathematics]. Studies in Educational Research and Development, 1 (1), 109- 131.

Lee, J. S., \& Ginsburg, H. P. (2007). Preschool teachers' beliefs about appropriate early literacy and mathematics education for low- and middle-socioeconomic status children. Early Education and Development, 18(1), 111-143. doi: 10.1080/10409280701274758

Maasepp, B., \& Bobis, J. (2014). Prospective primary teachers' beliefs about mathematics. Mathematics Teacher Education and Development, 16(2), 89-107.

National Council of Teachers of Mathematics (NCTM), 2000. Principles and Standards for school Mathematics. Reston. VA: The National Council of Teachers of Mathematics.

Oğuzkan, Ş., \& Oral, G. (1997). Okul öncesi eğitimi [Pre-school education]. İstanbul: Milli Eğitim Basımevi.

Oktay, A. (2000). Yaşamın Sihirli Yılları [Magic years of life]. İstanbul: Epsilon Yayınları.

Pajares, M. F. (1992). Teachers' beliefs and educational research: Cleaning up a messy construct. Review of Educational Research, 62, 307-332.

Raymond, A. M. (1997). Inconsistency between a beginning elementary school teacher's mathematics beliefs and teaching practice. Journal for Research in Mathematics Education, 28, 550-577. 
Zeynep Bahar Erşen, Nimet Akin \& Fatih Karakuş, Investigation of Prospective Preschool Teachers'...

Swars, S., Hart, L. C., Smith, S. Z., Smith, M. E., \& Tolar, T. (2007). A longitudinal study of elementary pre-service teachers' mathematics beliefs and content knowledge. School Science and Mathematics, 107(8), 325-335. doi:10.1111/j.1949-8594.2007.tb17797.x

Swars, S., Smith, S., Smith, M., \& Hart, L. (2009). A longitudinal study of effects of a developmental teacher preparation program on elementary prospective teachers' mathematics beliefs. Journal of Mathematics Teacher Education, 12(1), 47-66. doi:10.1007/s10857008-9092-x

Wortham, C. S. (2006). Early childhood curriculum, developmental bases for learning and teaching (Fourth edition). New Jersey: Pearson/ Merrill/Prentice Hall.

Tarım, K. \& Bulut, M. S. (2006). Okulöncesi öğretmenlerinin matematik ve matematik öğretimine ilişkin algı ve tutumları [Preschool teachers' perceptions and attitudes towards mathematics and mathematics teaching]. Çukurova Üniversitesi Eğitim Fakültesi Dergisi, 3(32), 152-164.

Tatto, M. T., Schwille, J., Senk, S., Ingvarson, L., Peck, R., \& Rowley, G. (2008). Teacher Education and Development Study in Mathematics (TEDS-M): Conceptual framework. East Lansing, Ml: Teacher Education and Development International Study Center, College of Education, Michigan State University.

Tavşancıl, E. (2006). Tutumların Ölçülmesi ve SPSS ile Veri Analizi [Measuring Attitudes and Data Analysis with SPSS]. Ankara: Nobel Yayın Dağıım.

Thompson, A. (1992). Teachers Beliefs and Conceptions: A Synthesis of the Research In: Handbook of Research on Mathematics Learning and Teaching, Grouws, A.D. (Ed.). Macmillan, New York, pp:127-146.

Todd- Brown, E. (2003). The influence of teachers' efficacy and beliefs on mathematics instruction in early childhood classroom (Doctoral Dissertation). Available from ProQuest Dissertation and Theses database. (UMI No: 3100998).

Vacc, N. N., \& Bright, G. W. (1999). Elementary preservice teachers' changing beliefs and instructional use of children's mathematical thinking. Journal for Research in Mathematics Education, 30(1), 89-110.

Wilkins, J., \& Brand, B. (2004). Change in preservice teachers' beliefs: An evaluation of a mathematics methods course. School Science and Mathematics, 104(5), 226-232. doi:10.1111/j.1949-8594.2004.tb18245.x

Yazıcıoğlu, Y., \& Erdoğan, S. (2007). SPSS Uygulamalı Bilimsel Araştırma Yöntemleri [SPSS Applied Scientific Research Methods] (2.Baskı). Ankara: Detay Yayıncılık. 
Yu, H. (2008). A comparison of mathematics teachers' beliefs between England and China. In Joubert, M. (Ed.) Proceedings of the British Society for Research into Learning Mathematics 28(2).

Zacharos, K., Koliopoulos, D., Dokimaki, M., \& Kassoumi, H. (2007). Views of prospective early childhood education teachers, towards mathematics and its instruction. European Journal of Teacher Education, 30(3), 305-318. doi:10.1080/02619760701486134

Zakaria, E., \& Musiran, N. (2010). Beliefs about the nature of mathematics, mathematics teaching and learning among trainee teachers. The Social Sciences 5(4), 346-351. doi: $10.3923 /$ sscience.2010.346.351 presentation at the International Science and Education Congress between 23-25 March 2018. 